\title{
Um jogo didático como proposta de intervenção pedagógica na abordagem sobre o mosquito Aedes aegypti
}

\section{Carolini Rosa Ryzy}

carol ryzy@hotmail.com

0000-0002-7644-4965

UniGuairacá Centro Universitário,

Guarapuava, Paraná, Brasil.

Ana Lúcia Crisostimo anacrisostimo@hotmail.com 0000-0001-9909-9300

Universidade Estadual do Centro Oeste, Guarapuava, Paraná, Brasil.

\begin{abstract}
RESUMO
Este trabalho socializa os resultados de uma pesquisa cujo objetivo foi avaliar as contribuições de um jogo didático na abordagem do mosquito Aedes aegypti, junto a alunos da Educação Básica, de modo a viabilizar a aprendizagem significativa. Participaram na investigação, de natureza qualitativa, 45 alunos do 60 ano do Ensino Fundamental de uma escola particular de Guarapuava-PR, em 2017. Para a coleta de dados foram utilizados um pré e um pós-teste, respetivamente, antes e depois do desenvolvimento de aulas, que contemplaram, em uma das etapas, a aplicação do jogo de tabuleiro intitulado "Batalha viral: combatendo o mosquito Aedes aegypti". Como resultados, foi possível observar que a intervenção foi eficiente, pois favoreceu a participação ativa dos alunos na construção do seu conhecimento e mostrou que trabalhos com ações de educação em saúde devem ser realizados nas escolas, pois é de extrema importância para a prevenção de surtos das doenças causadas pelo vetor, já que o aluno pode ser um propagador de conhecimento.
\end{abstract}

PALAVRAS-CHAVE: Aprendizagem significativa. Ensino de ciências. Atividade lúdica. 


\section{INTRODUÇÃO}

A partir da metade do século XX, emergiram novas teorias sobre a educação no Brasil, sendo uma delas a teoria construtivista, propondo que o aluno tenha um aprendizado através da interpretação de informações, construindo assim um novo significado para tal informação (ARGENTO, 2009). Gregorio e Pereira (2012, p. 55), apontam que "[...] no construtivismo o aluno é o ator principal no processo da aprendizagem, é ele que constrói e reconstrói seus conhecimentos numa reflexão individual e na interação com seus iguais".

Espera- se que no construtivismo ocorra a construção de um novo conhecimento, o qual ocorre a partir de um pré-existente, e esse fato pode ser compreendido a partir da Teoria de Ausubel, a qual espera que o aluno tenha uma aprendizagem significativa. $O$ educando traz o seu conhecimento prévio e estes se chocam com os conhecimentos passados na escola (CHAKUR, 2015). Portanto, na aprendizagem significativa o "[...] sujeito é o elemento estruturante do seu próprio conhecimento" (VALADARES, 2011, p. 40).

Para promover a aprendizagem significativa, particularmente no ensino de Ciências, o professor tem papel fundamental no processo, pois é ele que propicia levar o aluno a uma reflexão e não só à transmissão do conhecimento científico. Para que isso ocorra, o professor deve encontrar métodos de ensino diferenciados para aplicar na sua aula. Hoje com o avanço da tecnologia, existem vários facilitadores da aprendizagem, os quais são utilizados conforme a realidade e exigência da escola, pois por meio deles, o cognitivo dos alunos é estimulado de forma desafiadora e interessante. Entre esses facilitadores está a inserção do lúdico em sala de aula.

O lúdico pode ser trabalhado através de jogos, pois eles proporcionam momentos de interação, afetividade e favorecem a criatividade do aluno. Além disso, despertam interesse do aluno para o conteúdo. Assim, os jogos didáticos propõem um desafio ao professor: sair da rotina de suas aulas teóricas. Kishimoto (1996) destaca que os jogos didáticos auxiliam na construção do conhecimento, já que ele proporciona a motivação que é característica do lúdico.

Para corroborar com tais aportes teóricos, este artigo apresenta os resultados de uma pesquisa cujo objetivo foi avaliar as contribuições de um jogo didático na abordagem do mosquito Aedes aegypti, junto a alunos da Educação Básica, de modo a viabilizar a aprendizagem significativa. Para tanto o presente retrata em um primeiro momento uma fundamentação teórica que aborda a aprendizagem significativa e o ensino de ciências, o jogo como atividade lúdica no ensino, a metodologia utilizada na pesquisa e a descrição do jogo didático utilizado na ação pedagógica, os resultados e as considerações finais.

\section{REFERENCIAL TEÓRICO}

\subsection{Aprendizagem significativa no ensino de ciências}

Com a evolução da humanidade, o conceito de aprendizagem teve que ser mais ativo, pois aprender se tornou uma exigência e, nos dias de hoje, a aprendizagem comportamental (refletida através do comportamento e se desenvolve por meio de estímulos e respostas) não é mais suficiente para a 
sobrevivência no mundo atual. Além disso, no futuro dependerá da habilidade de aprender e desaprender com certa habilidade (SANTOS, 2008).

O conceito de aprendizagem significativa como um processo de assimilação substantiva, foi estabelecido por David Ausubel (1963). Para Ausubel, a aprendizagem significativa é quando novas informações interagem com ideais previas, existentes na estrutura cognitiva do indivíduo que aprende. Assim, os conhecimentos prévios conseguem ter uma maior estabilidade cognitiva ou acabam adquirindo novos significados (MOREIRA, 2011).

A esta componente da estrutura cognitiva especificamente relevante para assimilar cada conhecimento a aprender Ausubel atribuiu o termo "subsunçor", palavra que talvez tenha ido buscar à filosofia de Kant, onde o verbo subsumir significa a incorporação de um indivíduo numa espécie, a inferência de uma ideia a partir de uma lei, etc (VALADARES, 2011, p. 37).

O entendimento de uma determinada ideia ou um novo conceito deve ser assimilado e ter significado para quem aprende. Assim, novas informações tem de interagir com as ideias prévias do aprendiz previamente assimiladas. Tais ideias, mais ou menos familiares a quem aprende, são os subsunçores e assumem uma enorme importância na aprendizagem significativa (AUSUBEL, 1982). Os subsunçores podem ser ideias, concepções, modelos mentais e os conceitos que já existem na estrutura cognitiva da pessoa que está aprendendo, ou seja, são os conhecimentos prévios relevantes para a aprendizagem do novo (MOREIRA, 2011).

O armazenamento de informações do cérebro humano se dá de uma forma organizada, cujos elementos de conhecimentos gerais são assimilados com os específicos e mais inclusivos. Por isso, quanto mais organizada e estável for a estrutura cognitiva do educando, maior será a sua probabilidade de alcançar novas informações e realizar novas aprendizagens. Portanto, uma aprendizagem significativa só ocorre quando a nova informação adquirida se relaciona com os conceitos relevantes preexistentes na estrutura cognitiva (MOREIRA, 2011).

Afrontando com a aprendizagem significativa, Moreira e Masini (2001) Ausubel define a aprendizagem mecânica (rote learning), sendo esta a aprendizagem de novas informações com pouca ou nenhuma interação com os conceitos existentes. As novas informações podem ser adquiridas facilmente por meio da memorização verbal, aliando-se de maneira aleatória na estrutura de conhecimento de uma pessoa, sem interagir com os conceitos subsunçores específicos.

Conjeturando que a aprendizagem significativa deva ser elegida em relação a aprendizagem mecânica, pressupõem-se a existência dos conceitos subsunçores, porém muitas vezes o indivíduo não tem esses conceitos. Então, quando não existe subsunçores como pode ocorrer a aprendizagem significativa? Como os subsunçores se formam? (MOREIRA; MASINI, 2001).

Segundo Moreira e Masini (2001), a aprendizagem mecânica é necessária quando o indivíduo entra em contato com uma área de conhecimento completamente nova para ele. Isto é, a aprendizagem mecânica acontece até quando as novas informações na mesma área existirem na estrutura cognitiva, podendo servir de subsunçores mesmo sendo pouco elaborados. Conforme a aprendizagem inicia o processo de ser significativa, esses subsunçores ficam cada vez mais elaboradas e capazes de se ligar às novas informações. 
Outra resposta é que, em crianças, os conceitos são adquiridos mediante ao processo de formação de conceitos, o qual envolve a difusão de interesses específicos através da aquisição espontânea de ideias comuns por meio da experiência empírica. Mas quando essa criança atinge a idade escolar, a maioria delas possui um conjunto de conceitos que irá permitir a ocorrência da aprendizagem significativa por recepção. A aquisição de conceitos por meio da aprendizagem receptiva não é um processo indiferente de internalização, mas sim um processo de interação com os conceitos já adquiridos (MOREIRA; MASINI, 2001).

Ausubel recomenda o uso de organizadores prévios, pois muitas vezes o educando não possui subsunçores adequados para cominar significados às novas informações. Organizadores prévios são um recurso que serve como uma âncora de novas aprendizagens, as quais desenvolvem os conceitos subsunçores que facilitam a aprendizagem. A função desses organizadores é a de potencializar a criação de relações não-arbitrária e substantivas entre os novos conceitos (PRASS, 2012). Através desses organizadores, temos uma estratégia de manipular a estrutura cognitiva para facilitar a aprendizagem significativa, servindo como "pontes cognitivas" (MOREIRA, 2011).

Segundo Moreira (1999), os organizadores prévios não são tão facilitadores como Ausubel pensava, pois seu efeito na aprendizagem é pequeno. Se a pessoa que está aprendendo não tem um conhecimento prévio que seja relevante, não existe organizador que supra essa condição para ocorrer a aprendizagem significativa.

Para Santos (2008), a aprendizagem só acontece quando o aluno reconstrói o conhecimento e configura conceitos sólidos que possibilita que o aluno consiga agir e reagir perante a realidade. Com respaldo do mundo em que vivemos hoje, não há mais espaço para uma aprendizagem que não seja significativa, que não tenha contextualização, que seja somente uma repetição de informações. Para Santos (2008), a consolidação dessa aprendizagem se dá através de sete passos para a reconstrução do conhecimento.

No passo "sentir", o professor deve entender que o aluno precisa construir um real sentido em relação ao conteúdo, ou seja, o professor deve se preocupar em construir um sentido para o conteúdo apresentado. Já a etapa "perceber", só deve ser iniciada quando a etapa sentir já tiver sido construída, pois, assim, após o aluno perceber, ele conseguirá formar um conceito, já que irá compreender o conteúdo a partir do agrupamento de características e fatos percebidos (SANTOS, 2008).

Após a construção do conceito, o aluno deve "elaborar" uma definição e é nessa etapa que o professor consegue "avaliar" o nível de acerto dos alunos em relação à construção do conceito. Adequando o conceito por meio da definição, o aluno tem condição de "argumentar" e, se tem essa condição, ele pode discutir, ou seja, formar uma cadeia de raciocínios através da argumentação. Na fase da "discussão", o professor deve exigir do educando a coerência e a fundamentação do contexto. E, por último, temos a etapa "transformar" na qual o professor leva o aluno a simular uma ação no contexto real, pode resolver problemas e aplicar o conceito em sua vida (SANTOS, 2008). 


\subsection{Os jogos como atividade lúdica no Ensino de Ciências}

Sabendo das dificuldades de ministrar aulas de ciências, este estudo traz como tema central os jogos didáticos para tornar a sala de aula mais divertida e, consequentemente, favorecer a construção de conhecimento dos alunos.

De acordo com Almeida (2009), a palavra lúdico vem do latim 'ludus' e significa jogo, mas não se restringe a apenas a atividade de brincar e movimentar, visto que representa, também, aspectos do comportamento humano que perpassam os campos da personalidade, do corpo e da mente. A autora menciona ainda que a ludicidade faz parte da dinâmica do indivíduo e caracteriza-se por ser espontâneo e funcional, ou seja, não deve ser confundido com repetições sem objetivo que desperdiçam energia num movimento cíclico (ALMEIDA, 2009).

A utilização do lúdico como ferramenta didática vem sendo estudada desde os anos de 1990 e vem ganhando espaço nas escolas, principalmente na última década. E a cada dia que passa, o interesse em pesquisar o uso do lúdico no contexto escolar aumenta, pelo fato de poder trabalhar o ensino de forma mais "divertida" e diferente. Isso tem incentivado os professores a fazerem o uso dela (TEIXEIRA et al., 2017).

Estudos de Luckesi (2000) afirmam que a importância de atividades lúdicas está no fato de elas proporcionarem experiências plenas e saudáveis para a criança. Santin (2001) complementa que o lúdico é importante porque desenvolve ações não definíveis por palavras, visto que são imersas em fantasia, imaginação e sonhos através de teias organizadas com matérias simbólicas. Sendo assim, o prazer de atividades lúdicas está em sua singularidade por constituir-se de prazeres não estereotipados.

O importante da atividade lúdica não são apenas os resultados finais, mas sim todo o processo vivido, uma vez que os momentos de fantasia são compartilhados com o outro e ressignificados por cada indivíduo que dele participa.

$\mathrm{Na}$ opinião de Falkembach (2012), todas as atividades lúdicas agradam, pois prendem a atenção, entusiasmam, ensinam e transmitem diversas informações sem se tornar cansativo, atuando como facilitadoras do processo de ensino e aprendizagem. Ainda segundo Dinello (2004, p. 94), “[...]são nas atividades lúdicas que as crianças revelam a aprendizagem de habilidades, constroem relações criativas, aumentam a imaginação, socializam, acrescem seu vocabulário e se tornam independentes".

Entre os estudiosos da educação, Piaget (1976) foi quem defendeu que as atividades intelectuais das crianças têm na ludicidade obrigatoriamente o seu início. Para o autor, as atividades lúdicas não se resumem a entreter a criança a fim de que gaste energia, mas sim uma forma de auxiliar no desenvolvimento do intelecto:

As atividades lúdicas são cheias de simbolismo e ajudam na assimilação da realidade a partir da atividade própria, dando a esta seu combustível necessário e transformando o real de acordo com as necessidades múltiplas do eu. Nesse sentido, é conveniente fornecer materiais condizentes com a aprendizagem pelo meio lúdico, a fim de que as crianças assimilem as realidades intelectuais que, sem este, não seria possível (PIAGET, 1976, p. 109). 
Com esse posicionamento, torna-se evidente que a atividade lúdica no ambiente escolar proporciona envolvimento das crianças com a realidade criada, levando ao entendimento de diferentes aspectos que compõe o mundo real. Em salas de aula que a ludicidade é utilizada como componente de aprendizagem, o professor é o mediador do conhecimento, reconhecendo a importância do aluno que assume um posicionamento ativo e tem sua criatividade constantemente estimulada.

No ensino de ciências, a importância das práticas lúdicas tem ganhado espaço devido a necessidade de criar situações de ensino e aprendizagem mais atrativas (CARUSO; CARVALHO; SILVEIRA, 2002) do que as práticas tradicionalmente transmissivas, que ainda são as mais utilizadas em sala de aula. Balbino (2005) aponta que as experiências nos ambientes de aprendizagem revelam que a escola deve ser mais prazerosa, onde o aluno consiga vivenciar o conteúdo e ultrapassar os limites da sala de aula, indo para além do quadro negro, livros didáticos e terminologias científicas de ciências. De acordo com Campos et al., (2008), a ludicidade é uma importante ferramenta promotora da aprendizagem nas práticas da escola e deixa os alunos mais perto do conhecimento científico. A associação do lúdico ao ensino de ciências vem ocorrendo essencialmente por meio de jogos pedagógicos, histórias em quadrinhos, charges, teatros, desenhos (CARUSO; CARVALHO; SILVEIRA, 2002).

Ensinar a aprender pelo lúdico é um caminho que favorece a criatividade, a sensibilidade, a afetividade, as experiências físicas e emocionais, o pensamento e a linguagem. Quanto mais o professor tiver prazer em usar o lúdico em suas aulas, mais sucesso terá na assimilação das temáticas trabalhadas em sala de aula (SILVA, 2006). Um professor que busca a formação lúdica para incorporá-la nas suas aulas consegue reconhecer suas possibilidades e ter uma visão ampla da importância do jogo, da brincadeira e do brinquedo para a vida da criança (KISHIMOTO, 1992).

Na opinião de Falkembach (2012), entre as diversas atividades lúdicas que podem ser desenvolvidas, os jogos são as que mais transportam a criança ao ambiente de criatividade, conhecimento e socialização. Segundo Brenelli (1996), usar o lúdico como ferramenta de aprendizagem da criança é uma prática antiga advinda dos gregos e romanos e, para os novos ideais de ensino, ela pode ser colocada como forma de auxiliar nas demais tarefas escolares. Trabalhar a ludicidade é propor desafios à rotina escolar, fazendo com que a aprendizagem se prolongue para além da sala de aula, ocorrendo de maneira interessante e revelando as habilidades (FALKEMBACH, 2012).

\section{PROCEDIMENTOS METODOLÓGICOS}

Como mencionado anteriormente, os resultados ora apresentados, foram obtidos a partir da implementação do jogo de tabuleiro intitulado "Batalha viral: combatendo o mosquito Aedes aegypti" junto a alunos da educação básica. A referida prática ocorreu em um colégio particular de Guarapuava, Paraná e visou melhorar o processo de ensino aprendizagem sobre as doenças causadas pelo mosquito Aedes aegypti. A pesquisa aplicada, de natureza qualitativa, teve como participantes 45 alunos do 60 ano do Ensino Fundamental, durante as aulas de ciências no segundo semestre de 2017. 
Cabe mencionar que a pesquisa de natureza aplicada, está voltada ao desenvolvimento e avaliação de métodos e de produtos, tendo como objetivo a contribuição na prática, apontando para solucionar problemas de forma "palpável" e a curto prazo (BARROS E LEHFELD, 2000).

Metodologicamente, durante a pesquisa e antes da intervenção pedagógica, foi aplicado um pré-teste para averiguar o conhecimento prévio dos alunos participantes na ação investigativa. Ou seja, para averiguar o que sabiam sobre o mosquito Aedes aegypti. Nessa sondagem foi realizado um debate sobre o préteste que eles tinham respondido, além de levantar questões sobre os problemas enfrentados pela sociedade em relação ao Aedes aegypti. Após a aplicação foi dado sequência às aulas que contemplaram os seguintes conteúdos: A origem e morfologia do Aedes aegypti; hábitos, criadouros e doenças causadas pela picada do vetor.

Na sequência foi aplicado um jogo de tabuleiro que trabalha como um jogo de trilhas, pois existe um caminho que deve ser percorrido pelos peões que representa cada aluno participante (Figura 1 ).

Figura 1 - Jogo de tabuleiro: "Batalha viral: combatendo o mosquito Aedes aegypti"

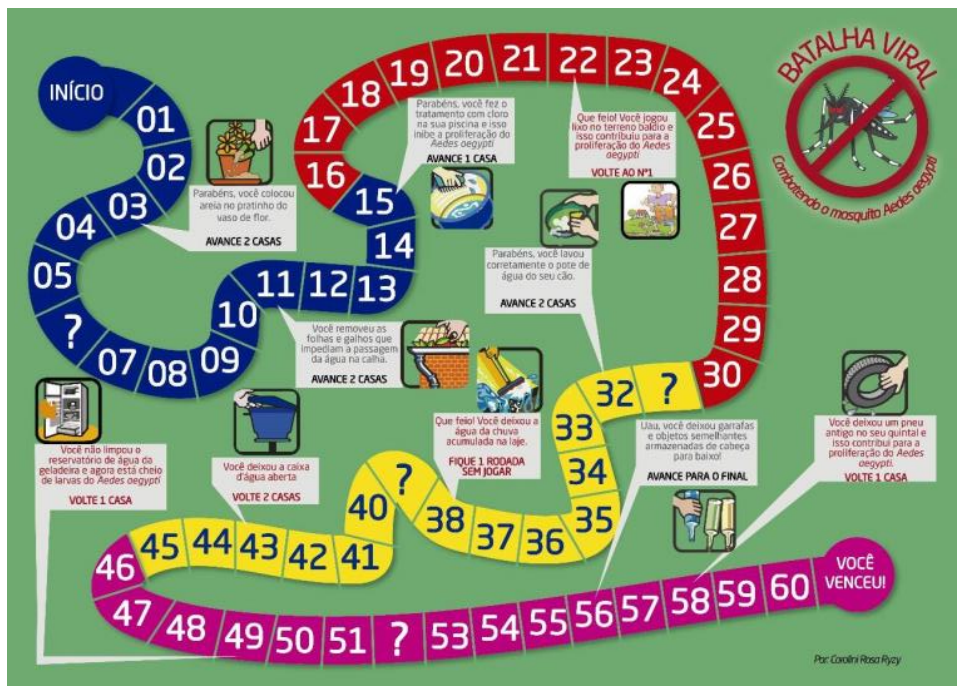

Fonte: Autora (2017).

O jogo de tabuleiro "Batalha viral: combatendo o mosquito Aedes aegypti" foi preparado para alunos do 6ㅇ ano do Ensino Fundamental, baseado nos Diretrizes Curriculares do Estado do Paraná - DCEs (2008). Nesse jogo espera-se que os alunos compreendam os seguintes conteúdos: Morfologia do mosquito Aedes aegypti, Hábitos, Criadouros e Doenças causadas pela picada do mosquito.

O jogo é motivacional e foi criado para ser jogado em grupos, sendo que cada grupo pode ser composto de três a seis jogadores. As esquipes devem receber um tabuleiro, seis peões, um dado, vinte cartas com perguntas, as regras do jogo e um cartão com as respostas.

As casas do tabuleiro são numeradas de um a sessenta. Em algumas casas existe a ilustração do ponto de interrogação, sinal que indica onde o jogador deve parar para responder a uma pergunta da carta-pergunta. Já em outras casas, as ilustrações contêm informações sobre a prevenção da proliferação do mosquito Aedes aegypti. Além dessas informações, existe um comando a ser seguido, o qual 
pode ser: "Volte à casa nำ1", "Avance 2 casas", "Avance para o final", "Volte 2 casas", entre outras.

Para saber em qual momento responder a carta-pergunta, o jogador precisa percorrer o caminho do tabuleiro e quando parar sobre a casa que tiver a ilustração da interrogação, esta irá levá-lo a responder uma pergunta. O participante que está respondendo a questão, tem que ler a pergunta e a resposta em voz alta para todos os integrantes do grupo. Quem aponta se está certa ou errada é o líder do grupo que foi escolhido no início do jogo e fica em mãos com todas as respostas. Em caso de acerto, existem passos na carta-pergunta para aperfeiçoar a sequência do jogo, como: "Avance duas casas", "Escolha um amigo para ficar uma jogada sem jogar", entre outras. Em caso de erro, os passos são: "Volte uma casa", "Fique uma rodada sem jogar", "Volte ao início do jogo", entre outras.

Além das indicações no tabuleiro, existe a pergunta surpresa que dinamiza ainda mais o jogo. Os jogadores serão surpreendidos em cinco momentos aleatórios (cinco questões). O jogador que estiver na vez, deve responder a pergunta surpresa que pode ser de verdadeiro ou falso ou de múltipla escolha. Se acertar, ele indica um dos jogadores para ficar uma rodada sem jogar ou voltar ao início do jogo ou, ainda, ele mesmo andar três casas no tabuleiro. Se errar, poderá ficar uma rodada sem jogar ou voltar ao início do jogo. O jogo só termina quando o penúltimo jogador completar o percurso.

Um dos motivos do jogo ser em equipes é responder em voz alta as questões dos temas citados e a partir da intervenção do líder cada jogador poderá avançar as casas até a chegada para ser vencedor.

O tabuleiro do jogo ora socializado, as regras e detalhes de como jogar está disponível em meio digital no repositório da Universidade Estadual do CentroOeste-PR, no banco de dissertações e teses, a saber: $<$ http://tede.unicentro.br:8080/ispui/bitstream/ispui/1246/3/Produto\%20Educac ional\%20-\%20CAROLINI\%20ROSA\%20RYZY.pdf> (RYZY, 2018).

Na etapa final da implementação foi aplicado um pós-teste e as análises qualitativas das referidas questões serão apresentadas a seguir.

\section{RESULTADOS E DISCUSSÕES}

Como mencionado, os resultantes contemplam as análises dos questionários aplicados em dois momentos distintos da pesquisa: um na fase inicial, o pré-teste e o mesmo questionário aplicado na etapa final da implementação. Participaram do pré-teste 45 alunos e 44 alunos no pós-teste, somente um não respondeu, pois faltou à aula em que foi aplicado. Portanto, deve-se ponderar na análise dos dados essa diferença no número de respostas. Do pós-teste

Primeiramente, questionou-se "Qual o país e o continente de origem do mosquito Aedes aegypti?. Esperava-se que os alunos assinalassem "Egito, na África".

Segundo Gomes (2016), o mosquito Aedes aegypti recebeu esse nome que significa "o odioso do Egito", porque tem sua origem no norte da África, uma vez que foi encontrado nas florestas onde picava os primatas e, com o passar do tempo, adaptou-se a viver próximo aos seres humanos. Com o avanço da movimentação de pessoas e objetos em vários lugares do mundo, o mosquito teve 
sua propagação e, por meio do transporte náutico negreiro, ele chegou às Américas no século XVII, onde teve seus primeiros registros de febre amarela.

No pré-teste, observou-se que 30 alunos assinalaram no "Brasil, América do Sul", 11 "Egito, na África", 3 no "Japão, Ásia" e 1 "Argentina, América do Sul”. No pós-teste foram: 41 alunos que assinalaram "Egito, na África" e 3 "Brasil, América do Sul".

Percebe- se que existe um aumento significativo na alternativa que indicava a resposta "Egito, na África". Isso mostra que os alunos conseguiram organizar adequadamente as informações recebidas.

Na segunda questão, os alunos podiam responder mais de uma alternativa, pois ela trazia o seguinte questionamento: "Como você obtém informação(ões) sobre o mosquito Aedes aegypti?". Do total, 43 alunos responderam que obtêm as informações através da televisão e 28 alunos assinalaram jornais, revistas e cartazes. Já na opção "escolas", foram 17 alunos que assinalaram a alternativa.

O resultado mostra que a maioria dos alunos obtém informações através de meios de comunicação. Segundo Ribeiro e Batista (2010, p. 5) "[...] dentre as funções que os meios de comunicação têm (informar, entreter, difundir cultura) está o papel de educar, que pode ser executado tanto através da programação (programas educativos, como o Telecurso 2000)". Porém, é fundamental que no ambiente escolar o aluno receba as competências necessárias, pois assim consegue realmente compreender as informações que ele obteve através das mídias. Além disso, o aluno consegue realizar uma análise crítica diante das informações recebidas.

Na seguinte, questionava-se: "Para identificar o mosquito Aedes aegypti, qual característica deve ser observada?". A resposta almejada era "a coloração do corpo", uma das principais características que pode ser observada para realizar a identificação, pois o mosquito tem coloração escura e listras brancas no corpo e nas pernas.

No pré-teste, 30 alunos assinalaram "a coloração do corpo", 10 alunos "a divisão do corpo", 4 alunos "a presença de antenas" e 1 aluno "o número de asas". Já no pós-teste, 35 alunos responderam "a coloração do corpo", 7 alunos "a divisão do corpo" e 2 alunos "a presença de antenas". Quanto aos alunos que responderam errado no pós-teste, pode ser que ainda estivessem em um processo de assimilação de conceitos que, talvez, não estivessem estruturados cognitivamente. Para tanto, o aluno deve ter subsunçores apropriados para que novas informações consigam se ancorar, pois segundo Lara e Sousa (2009, p. 63) "[...] a informação precisa ser ancorada em subsunçores de maneira que essa ancoragem faça algum sentido para o aluno. Assim, ele precisa conhecer algo que possibilite uma relação com o que ele quer aprender".

Por meio desse resultado, percebe- se que a maioria dos alunos assinalaram a alternativa correta nos dois testes, o que significa que eles já tinham um conhecimento prévio sobre o tema e que as informações recebidas ratificaram esse conhecimento. Sobral e Teixeira (2006) destacam que: 
conheça o que o estudante já sabe para que possa conduzir uma abordagem segura em relação ao conteúdo que pretende ensinar (SOBRAL; TEIXEIRA, 2006, p. 5).

Quando indagados sobre "Ao ser picado por um mosquito (macho e/ou fêmea) Aedes aegypti, podemos afirmar que." Esperava-se que os alunos respondessem: "Trata-se de uma fêmea, pois elas são as únicas capazes de picar os seres humanos".

Segundo o Instituto Oswaldo Cruz (2011), tanto o macho como a fêmea se alimentam de néctar, seiva e nutrientes que contêm açúcar. Porém, a fêmea também faz a ingestão de sangue humano para poder produzir os seus ovos. Como o macho não produz ovos, ele não precisa consumir sangue.

No pré-teste 18 alunos responderam que "trata-se de uma fêmea, pois elas são as únicas capazes de picar os seres humanos", 14 responderam que "contraímos a chikungunya, pois todos os mosquitos são contaminados.", 12 assinalaram a alternativa que "adquirimos várias bactérias, como a causadora da malária." e 1 aluno assinalou que "trata-se de um macho, pois os machos são os únicos capazes de picar os seres humanos.". No pós-teste, houve uma melhora significativa: 35 alunos responderam que "trata-se de uma fêmea, pois elas são as únicas capazes de picar os seres humanos", 6 alunos assinalaram que "adquirimos várias bactérias, como a causadora da malária." , 2 responderam que "contraímos a chikungunya, pois todos os mosquitos são contaminados." e 1 assinalou que "trata-se de um macho, pois os machos são os únicos capazes de picar os seres humanos".

Outro questionamento era sobre a transmissão das doenças relacionadas ao mosquito Aedes aegypti. Esperava- se que os alunos assinalassem a alternativa que apresentava a seguinte resposta: "No Brasil, a transmissão do zika vírus e outras doenças ocorre pelo Aedes aegypti, entretanto, o Aedes albopictus existente no país, apresenta potencial para transmitir a doença.". Segundo Luz et al., (2015), o vírus Zica é transmitido sobretudo pelos mosquitos Aedes albopictus e Aedes aegypti, além da transmissão por relações sexuais, transfusão sanguínea e de mãe para feto. No pré-teste, 20 alunos assinalaram a alternativa correta, a saber: "no Brasil, a transmissão do zika vírus e outras doenças ocorre pelo Aedes aegypti, entretanto, o Aedes albopictus existente no país, apresenta potencial para transmitir a doença.", 12 alunos marcaram que "todos os mosquitos Aedes aegypti possuem o vírus causador da chikungunya.", 9 alunos assinalaram que "o culpado pela transmissão da febre amarela para seres humanos é o macho do mosquito Aedes aegypti." e 4 alunos assinalaram que "machos e fêmeas, transmitem o vírus causador do zika vírus.". Já no pós-teste, 36 alunos responderam que "no Brasil, a transmissão do zika vírus e outras doenças ocorre pelo Aedes aegypti, entretanto, - Aedes albopictus existente no país, apresenta potencial para transmitir a doença." , 4 alunos marcaram que "todos os mosquitos Aedes aegypti possuem o vírus causador da chikungunya.", 3 alunos assinalaram que "o culpado pela transmissão da febre amarela para seres humanos é o macho do mosquito Aedes aegypti." e 1 aluno assinalou que "machos e fêmeas, transmitem o vírus causador do zika vírus."

Pode ser observado que houve uma melhora significativa no número de respostas corretas e, consequentemente, é possível opinar que houve ganhos cognitivos a partir das aulas teóricas e da aplicação do referido jogo. 
O professor deve ser um facilitador no processo de ensino, pois é ele que deve auxiliar na assimilação de conteúdo e na reorganização da própria estrutura cognitiva. É o professor que vai ser o mediador da aquisição de novos significados e, consequentemente, gerar novos conceitos (MOREIRA; MASINI, 2001).

Quando perguntados sobre: "As condições socioambientais que favorecem o desenvolvimento e a proliferação do vetor Aedes aegypti são:", esperava- se que os alunos assinalassem a alternativa com a resposta: "Em regiões onde não existe o fornecimento regular de água, moradores armazenam o suprimento de água limpa em recipientes abertos.". Segundo Pinto et al., (2013), a água limpa e temperatura elevada são combinações perfeitas para a fêmea depositar os seus ovos.

No pré-teste, 26 alunos assinalaram a alternativa correta "Em regiões onde não existe o fornecimento regular de água, moradores armazenam o suprimento de água limpa em recipientes abertos", seguido de 9 respostas para "Vasos de flores mantidos em pratos com areia são possíveis criadouros.", 6 alunos assinalaram "Caixa de água mantidas fechadas" e 4 respostas para "Locais com frutas e verduras em decomposição". No pós-teste, 34 alunos assinalaram "Em regiões onde não existe o fornecimento regular de água, moradores armazenam o suprimento de água limpa em recipientes abertos", seguido de 4 alunos que responderam "Vasos de flores mantidos em pratos com areia são possíveis criadouros.", 4 "Caixa de água mantidas fechadas" e 2 respostas para "Locais com frutas e verduras em decomposição"

Podemos observar que houve um aumento significativo em relação à alternativa correta. Porém, mesmo após a intervenção, 10 alunos assinalaram alternativas incorretas. Isso pode ter acontecido pela falta de organizadores prévios. Recomenda-se o uso de organizadores prévios, pois muitas vezes o educando não possui subsunçores adequados para cominar significados às novas informações. Organizadores prévios são um recurso que serve como uma âncora de novas aprendizagens que desenvolve os conceitos subsunçores e que facilitam a aprendizagem. Sua função é a de potencializar a criação de relações nãoarbitrárias e substantivas entre os novos conceitos (PRASS, 2012). Para Moreira por meio dos organizadores prévios temos uma estratégia de manipular a estrutura cognitiva para facilitar a aprendizagem significativa, servindo como "pontes cognitivas".

O último questionamento foi o seguinte: "Que proposta(s) preventiva(s) poderia(m) ser efetivada(s) para diminuir a reprodução do mosquito Aedes aegypti?". No pré-teste, 39 alunos assinalaram "Eliminar qualquer tipo de recipiente que possa acumular água, porque as larvas do mosquito se desenvolvem nesse meio." e 6 alunos assinalaram "Lavar bem as frutas e verduras, pois as larvas do mosquito se desenvolvem nesse tipo de substrato". Já no pósteste, 42 os alunos responderam "Eliminar qualquer tipo de recipiente que possa acumular água, porque as larvas do mosquito se desenvolvem nesse meio.", 1 assinalou a alternativa "Lavar bem as frutas e verduras, pois as larvas do mosquito se desenvolvem nesse tipo de substrato." e 1 aluno a alternativa "Instalação de telas nas janelas, pois o mosquito necessita de ambientes cobertos para a sua reprodução."

Percebe- se que maioria dos alunos respondeu a alternativa correta tanto no pré-teste como no pós-teste, o que mostra que os mesmos já conheciam sobre as 
prevenções do mosquito e o jogo veio colaborar com esse conhecimento. $\mathrm{O}$ fato de a maioria dos alunos acertarem essa questão no pré-teste, pode estar associado à divulgação de ações preventivas pela mídia.

Em uma perspectiva global os resultados da pesquisa apontam que durante a intervenção houve ganhos cognitivos significativos sobre o mosquito Aedes aegypti. Nesse processo, o professor tem papel fundamental, pois é ele que deve promover situações para que de fato aconteça a construção e reconstrução do conhecimento, uma vez que o professor é o mediador entre o conhecimento do cotidiano (aquele vivenciado pelo aluno) e o conhecimento escolar. Além disso, é importante que o professor utilize metodologias de ensino lúdicas que motivem seus alunos, visando uma aprendizagem significativa, como no caso exposto, via a utilização de jogos didáticos.

Mesmo antes da aplicação do jogo, os alunos se mostraram ansiosos para participar. Durante as aulas teóricas estavam fazendo anotações sobre o conteúdo, pois eles sabiam que os conteúdos das aulas teóricas estariam no jogo. Esse fato mostrou que os alunos tiveram um estímulo para aprender e se dedicar ao conteúdo. Segundo Melo et al., (2017) é necessário que o aluno sinta prazer de estudar os conteúdos, pois dessa forma conseguimos alcançar uma aprendizagem de qualidade, já que o aluno vai sentir interesse e motivação para aprender. Através de atividades lúdicas, o aluno motivado tem a sua criatividade e o desejo de aprender aflorados, assim, auxiliando no desenvolvimento da sua capacidade de solucionar problemas do seu cotidiano.

Além de estimular o interesse do aluno, a aplicação do jogo didático "Batalha viral: combatendo o mosquito Aedes aegypti" proporcionou aos alunos no decorrer da intervenção, momentos de interação e participação ativa dos alunos por meio de questionamentos e posicionamentos críticos em relação ao papel social de cada um. O cidadão deve ser responsável, desde a mais tenra idade, por ações preventivas em relação às causas das doenças causadas pelo mosquito $A$. aegypti que é vetor de várias doenças como dengue, zika, chikungunya e febre amarela.

Foi possível também observar a participação ativa dos alunos em sala de aula, o que permitiu que eles expusessem para seus colegas seus conhecimentos prévios e adquiridos durante a intervenção, além de ter permitido que fizessem reflexões críticas sobre o tema abordado. Silva et al., (2015) afirmam que a utilização dos jogos em sala de aula mantem uma relação interpessoal entre os participantes, pois o foco é uma atividade dinâmica e lúdica diferentemente das aulas expositivas centradas na aprendizagem passiva e mecânica, por fim desinteressantes. Com isso, os alunos conseguem exercitar sua mente, criar e aceitar ideias diferentes, além de melhorar sua interação com os seus colegas do grupo.

É pertinente dizer que a intervenção foi eficaz na ascensão da aprendizagem significativa, já que os jogos possibilitam a aproximação do conteúdo ao cotidiano do aluno, podendo manifestar uma predisposição para aprender. Assim, os alunos saíram da rotina da aprendizagem mecânica, através da transmissão do conhecimento e passaram a ter uma aprendizagem significativa de maneira ativa. 


\section{CONSIDERAÇÕES FINAIS}

Hoje a sociedade vive em torno de ao menos um tipo de tecnologia, e isso, sugere muitas mudanças na prática do professor e na relação professor-aluno, uma vez que o educador deve estar em constante atualização para garantir uma aprendizagem significativa aos seus alunos. Sendo assim, os jogos didáticos podem ser considerados um auxílio importante para os professores de ciências, pois através deles é possível motivar os alunos a aprenderem conhecimentos científicos, relacionando-os diretamente com o cotidiano.

A partir dos resultados obtidos na pesquisa, ora socializada, a aplicação do jogo didático "Batalha viral: combatendo o mosquito Aedes aegypti" reforçou os conhecimentos já aprendidos pelos alunos no cotidiano intra e extra escolar, enriquecendo os mesmos com aprofundamentos teóricos sobre mosquito $A$. aegypti no tocante à sua morfologia, transmissão de doenças e modos de prevenção. Neste contexto é possível inferir que a experiência pedagógica tenha oportunizado uma aprendizagem significativa. 


\title{
A DIDACTIC GAME AS A PEDAGOGICAL INTERVENTION PROPOSAL IN THE APPROACH TO THE AEDES AEGYPTI MOSQUITO
}

\begin{abstract}
This work socializes the results of a research whose objective was to evaluate the contributions of a didactic game in the approach of the Aedes aegypti mosquito, with students of Basic Education, in order to make meaningful learning possible. 45 qualifying students from the 6th year of elementary school of a private school in Guarapuava-PR participated in the research, in 2017. For data collection, a pre and a post-test were used, respectively, before and after the development. of classes, which contemplated, in one of the stages, the application of the board game entitled "Viral battle: fighting the Aedes aegypti mosquito". As a result, it was possible to observe that the intervention was efficient, as it favored the active participation of students in the construction of their knowledge and showed that work with health education actions should be carried out in schools, as it is extremely important for the prevention of outbreaks. diseases caused by the vector, since the student can be a propagator of knowledge.
\end{abstract}

KEYWORDS: Meaningful learning. Science teaching. Playful activity. 


\section{REFERÊNCIAS}

ALMEIDA, A. Ludicidade como instrumento pedagógico. Cooperativa do Fitness CDOF, Belo Horizonte, Minas Gerais, 2009. Disponível em: Acesso em: 12 mar. 2018.

ARGENTO, H. Teoria construtivista. 2008. Disponível em: <http://www.robertexto.com/archivo5/teoria construtivista.htm/>. Acesso em: 06 fev. 2018.

AUSUBEL, D. P. A aprendizagem significativa: a teoria de David Ausubel. São Paulo: Moraes, 1982.

BALBINO, M. C. Uso de modelos, numa perspectiva lúdica, no ensino de ciências. In: encontro ibero-americano de coletivos escolares e redes de professores que fazem investigação na sua escola, 4. 2005. Anais... Lajeado, Rio Grande do Sul, UNIVATES, 2005.

BARROS, A. de J. P.; LEHFELD, N. A. de S. Projeto de pesquisa: propostas metodológicas. Rio de Janeiro: Vozes, 2000.

CAMPOS, L. M. L.; BORTOLOTO, T. M.; FELICIO, A. K. C. A produção de jogos didáticos para o ensino de ciências e biologia: uma proposta para favorecer a aprendizagem. 2008. Disponível em: $<$ http://www.unesp.br/prograd/PDFNE2002/aproducaodejogos.pdf $>$. Acesso em :16 abr. 2018.

CARUSO, F.; CARVALHO, M.; SILVEIRA, M. C. Uma proposta de ensino e divulgação de ciências através dos quadrinhos. Ciência e Sociedade, Campinas, v. 8, n.2, p. 1-9, 2002.

CHAKUR, C. R. S. L. A desconstrução do construtivismo na educação: Crenças e equívocos de professores, autores e críticos [online]. São Paulo: Editora UNESP, 2015, $171 \mathrm{p}$.

DINELLO, R. Os jogos e as ludotecas. Santa Maria: Pallotti, 2004.

FALKEMBACH, M. F. Quem disse que não tem espaço pra dançar na escola? In: FERREIRA, Taís; FALKEMBACH, Maria Fonseca. Teatro e dança nos anos iniciais. Porto Alegre: Mediação, 2012, p. 59-129. 
pesquisa/fiquePorDentro/temas/aedes-aegypti/texto-base-da-consultorialegislativa-em-pdf>. Acesso em: 19 mar. 2018.

GREGORIO, M. P. F.; PEREIRA, S. P. Construtivismo e aprendizagem: uma reflexão sobre o trabalho docente. Revista Educação, Batatais, v. 2; n. 1, p. 51- 66, jun. 2012.

INSTITUTO OSWALDO CRUZ, 2011. Curiosidades sobre o Aedes aegypti. Disponível em: <http://www.ioc.fiocruz.br/dengue/textos/curiosidades.html>. Acesso em: 18 mar. 2018.

KISHIMOTO, T. M. Jogo, Brinquedo, Brincadeira e a Educação. São Paulo: Cortez, 1996.

Jogos Infantis: O jogo, a criança e a educação. Petrópolis: Vozes, 1992.

LARA, A. E. de; SOUSA, C. M. S. G. de. O processo de construção e de uso de um material potencialmente significativo visando a aprendizagem significativa em tópicos de colisões: apresentações de slides e um ambiente virtual de aprendizagem. Experiências em Ensino de Ciências, Rio Grande do Sul, v. 4, n. 2, p.61-82, jan. 2009.

LUCKESI, C. C. (Org.). Educação, ludicidade e prevenção das neuroses futuras: uma proposta pedagógica a partir da Biossíntese. Educação e Ludicidade: Coletânea Ludopedagogia Ensaios, Salvador, n. 1, p. 21-32, 2000.

LUZ, K. G; SANTOS, G. I. V. dos; VIEIRA, R. de M. Febre pelo vírus Zika.

Universidade Federal do Rio Grande do Norte, Instituto de Medicina Tropical, Natal-RN, Brasil. Epidemiologia Serv. Saúde, Brasília, 24(4):785-788, out-dez 2015.

MELO, A. C. A.; ÁVILA, T. M.; SANTOS, D. M. C. Utilização de jogos didáticos no ensino de Ciências: um relato de caso. Ciência Atual, Rio de Janeiro, v. 9, n. 1, p.1-14, 2017.

MOREIRA, A. M. Teorias de Aprendizagem. EPU: São Paulo, 1999. 151-165p.

Aprendizagem significativa: a teoria e textos complementares. São Paulo: Livraria da Física, 2011. 179 p. 
PARANÁ. Secretaria de Estado da Educação. Diretrizes Curriculares do Estado do Paraná. Curitiba: SEED, 2008.

PIAGET, J. A Equilibração das Estruturas Cognitivas. Problema central do desenvolvimento. Trad. Álvaro Cabral. Rio de Janeiro: Zahar, 1976.

PINTO, P. de S.; PINTO, F. de O.; DUARTE, S. C. A Dengue e sua relação com Educação Ambiental no município de Quissamã. RJ. Revista Científica da Faculdade de Medicina de Campos, v. 8, n. 1, p. 14-18, mai. 2013.

PRASS, A. R. Teorias de aprendizagem. Editora e-book: SriniaLibris.com, 2012. 57p. Disponível em: $<$ http://www.fisica.net/monografias/Teorias de Aprendizagem.pdf $>$. Acesso em: 19 jul. 2017.

RIBEIRO, A. C.; BATISTA, A. de J. A influência da mídia na criança / préadolescente e a educomunicação como mediadora desse contato. 2010. $10 \mathrm{f}$. Monografia (Graduação) - Curso de Comunicação Social Com Habilitação em Jornalismo, Universidade Federal do Tocantins, Palmas, 2010.

RYZY, C. R. Um jogo didático como proposta de intervenção pedagógica na abordagem sobre o mosquito Aedes aegypti à lua da teoria da aprendizagem significativa. 2018. 77f. Dissertação- Programa de Mestrado em Ensino de Ciências Naturais e Matemática, Universidade Estadual do Centro-Oeste, Guarapuava -PR.

SANTIN, S. Educação Física: da alegria do lúdico à opressão de rendimento. Porto Alegre: STF edições, 2001.

SANTOS, J. C. F. dos. O desafio de promover a aprendizagem significativa. 2008. Disponível em: http://www.juliofurtado.com.br/textodesafio.pdf. Acesso em: 17 jul. 2017.

SILVA, A. P. L. C. O lúdico na educação infantil: concepções e práticas dos professores na rede municipal de Campo Grande, MS. 187f. 2006. Dissertação (Mestrado em Educação), Universidade Católica Dom Bosco, 2006. ALMEIDA, L. I. M. V. de. Jogos Interativos: uma abordagem metodológica para auxiliar no processo ensino aprendizagem dos alunos do 6ㅇ e 7ㅇ anos na Escola Campos Sales em Juscimeira/MT. Revista Monografias Ambientais - REMOA Revista do Centro do Ciências Naturais e Exatas - UFSM, Santa Maria ED. ESPECIAL IFMT - Licenciatura em Ciências da Natureza - v.14, p.23-40, 2015. 
SOBRAL, A. C. M. B.; TEIXEIRA, F. M. Conhecimentos prévios: investigando como são utilizados pelos professores de ciências das séries iniciais do ensino fundamental. Anais... In: VI Encontro Nacional de Pesquisa em Educação em Ciências, 2006. Núcleo de Tecnologia Educacional para Saúde. Universidade Federal do Rio

TEIXEIRA, D. M.; MACHADO, F. B.; SILVA, J. S. da. O lúdico e o ensino de Geociências no Brasil: principais tendências das publicações na área de Ciências da Natureza. Terræ Didatica, n.13(3):286-294, 2017.

VALADARES, J. A teoria da aprendizagem significativa como teoria construtivista. Aprendizagem Significativa em Revista, v. 1, n. 1, p. 36- 57, 2011.

Recebido: 19 ago. 2018

Aprovado: 11 mai. 2020.

DOI: $10.3895 /$ rbect.v13n2.8712

Como citar: RYZY, C. R.; CRISOSTIMO, A. L. Um jogo didático como proposta de intervenção pedagógica

na abordagem sobre o mosquito Aedes aegypti. Revista Brasileira de Ensino de Ciência e Tecnologia

Ponta Grossa, v.13, n. 2, p. 269-286, mai./ago. 2020. Disponível em:

<https://periodicos.utfpr.edu.br/rbect/article/view/8712>. Acesso em: XXX.

Correspondência: Carolini Rosa Ryzy - carol ryzy@hotmail.com

Direito autoral: Este artigo está licenciado sō̄ os termos da Licença Creative Commons-Atribuição 4.0 Internacional. 